\title{
A INVERSÃO DA VERDADE. NOTAS SOBRE O NASCIMENTO DA TRAGÉDIA
}

\author{
Cláudia Maria de Castro* \\ claudiamariacastro@bol.com.br
}

RESUMO Este artigo desenvolve o tema da estética no pensamento de Nietzsche através das idéias fundamentais de seu primeiro livro, O nascimento da tragédia, ou Helenismo e pessimismo. Detendo-se especialmente na primeira parte desta obra, o estudo destaca a relação entre a arte e a verdade em sua filosofia, esclarecendo a união entre a ética e a estética, entre a vontade e o processo de simbolização das formas atísticas.

Palavras-chave Verdade; Estética; Afirmação; Tragédia; Nietzsche.

ABSTRACT This paper develops the theme of aesthetics in Nietzsche's thought through the fundamental ideas presented on his first book The Birth of Tragedy, or Hellenism and pessimism. Focusing mainly on the first part of this work, the study emphasizes the relationship between art and truth on his philosophy, highlighting the connection between ethics and aesthetics, between will and the process of symbolization of artistic forms.

Keywords Truth; Aesthetics; Affirmation; Tragedy; Nietzsche.

"Só na criação há liberdade"

(Nietzsche, verão de 1883)

* Professora do Departamento de Filosofia da Pontifícia Universidade Católica do Rio de Janeiro. Artigo recebido em julho de 2007 e aprovado em maio de 2008. 
A arte é um dos temas mais importantes da reflexão filosófica de Nietzsche. Nela, seu pensamento mergulhou apaixonadamente desde sua primeira grande obra, $O$ nascimento da tragédia, até seus últimos escritos. Sob o olhar deste filósofo, as relações que se estabelecem entre a arte e a verdade configuram o campo de forças onde se joga o grande jogo da vida e da morte. Eis a tarefa da arte: conferir um sentido à vida, dignificá-la, para nos seduzir a continuar vivendo. Em Nietzsche, há uma profunda conexão entre o processo de simbolização das formas artísticas e a força, a potência da vida que é a vontade (der Wille), nossa única verdade: "Nós temos a arte a fim de não morrer de verdade", ${ }^{1}$ escreveu o filósofo em seus Fragmentos póstumos. A ética e a estética convergem de forma essencial, porque ambas se constrõem a partir deste "traço de união entre carne e espírito", ${ }^{2}$ entre a força e a forma, que esta filosofia pioneira veio nos revelar.

Segundo Nietzsche, a vontade pontencializada - força que podemos chamar também de efusão ou euforia -, por ele nomeada de embriaguez, é o fundo e o motor de todo o esforço de criação. Por trás da atividade artística temos sempre uma espécie de subjetividade transbordada, intensiva, um "eu sou" que excede os limites da consciência e faz de seu júbilo a sua expressão. ${ }^{3}$ Essa subjetividade sem sujeito é o princípio desta estética que tem na relação entre a arte e a vontade seu problema central. Arte e vida se encontram porque o trabalho de simbolização das formas artísticas é uma experiência ética, de afirmação e exaltação da existência. Assim se compreende a célebre afirmação do filósofo que fulgura luminosa já no prefácio de $O$ nascimento da tragédia: "a arte é a tarefa suprema e atividade propriamente metafísica desta vida". ${ }^{4}$

Leitor e discípulo de Schopenhauer em sua primeira fase de produção, como seu mestre, Nietzsche concebe a vida como vontade, desejo, força

1 NIETZSCHE, Friedrich. Sämtliche Werke. Kritische Studienausgabe. Org. Giorgio Colli e Massimo Montinari. München: Deutscher Taschenbuch Verlag; Berlin/New York: Walter de Gruyer, 1967-77. 15 v. As referências a essa edição estão indicadas pelas iniciais KSA, seguidas do número do volume e da página. NIETZSCHE, Friedrich. CEuvres philosophiques complètes. Paris: Gallimard, 1968/1997. 18 v. Para esta edição francesa, as referências serão formadas do título da obra, do número de classificação do fragmento, seguido do número do volume e da página onde é possível encontrar a citação. Fragments posthumes 16[40] § 6-7, XIV, p. 250. - KSA, XIII, p. 500.

2 AUDI, Paul. L'Ivresse de l'art. Nietzsche et l'esthétique. Paris: Ed. Le Livre de Poche, 2003. p. 11.

3 Em Assim falou Zaratustra, Nietzsche profere expressamente: "Atrás de seus pensamentos e sentimentos, meu irmão, há um senhor mais poderoso, um sábio desconhecido - ele se chama 'eu sou' (Selbst). Habita teu corpo; é o teu corpo." NIETZSCHE, Friedrich. Assim falou Zaratustra: um livro para todos e para ninguém. Tradução de Mario da Silva. Rio de Janeiro: Civilização Brasileira, 2005, p. 60, modificada. - (KSA, IV, p. 40).

4 Idem, O nascimento da tragédia, ou Helenismo e pessimismo. Tradução, notas e posfácio J. Guinsburg. São Paulo: Companhia das Letras, 1992, p. 26 - (KSA, I, p. 24). A partir de agora, esta edição será citada apenas como NT. 
cega que escapa à razão humana. ${ }^{5}$ Do ponto de vista racional, a vida, em íntima imbricação com a morte, é absurda. Enquanto processo constante de construção e desconstrução, o mundo não é mais que um jogo, brincadeira de um deus criança que "assenta pedras aqui e ali e constrói montes de areia e volta a derrubá-los", ${ }^{6}$ conforme a misteriosa imagem de Heráclito. No entanto, essa filosofia pessimista exige uma arte otimista como remédio que cura e nos salva do "supremo perigo" da verdade insuportável. Ao contrário de Schopenhauer, para quem a única solução dada ao homem consiste, em última instância, na negação da vontade, Nietzsche concebe um pessimismo diferente, um pessimismo da potência ou "da fortitude", ${ }^{7}$ que conta com o feitiço da arte para transfigurar a horrenda verdade. Longe dos filósofos metafísicos - esses amigos da "verdade a qualquer preço" - que "querem expor à luz, desvelar, descobrir, tudo absolutamente que por boas razões é mantido oculto", ${ }^{8}$ Nietzsche não pretende desvendar o inescrutável; ele sustenta uma ética da criação, da glorificação da aparência, da mentira e da ilusão, em sua capacidade de inversão da verdade, de celebração tonificante, que torna a vida possível e digna de ser vivida. A necessidade da arte é explicada pela afirmação da vida, "pois só como fenômeno estético podem a existência e o mundo justificar-se eternamente". ${ }^{9}$ Como resposta à saída ascética de Schopenhauer, a vida como arte encontra seu sentido e o pensamento nietzscheano penetra no mistério ancestral da criação artística.

Enquanto filósofo da cultura, Nietzsche avalia e diagnostica: a cultura ocidental está doente, ela sofre de niilismo. ${ }^{10}$ Uma fraqueza dos instintos cujos sintomas manifestam-se em sua tradição filosófica, moral e religiosa. Psicólogo das profundezas, ao sondar as origens das formas de pensar responsáveis por este processo de decadência que corrói o mundo moderno, ele encontra o socratismo, o modo metafísico de pensar que se impôs como base de nossa civilização: o niilismo do qual padece o Ocidente é conseqüência direta do

5 No entanto, é preciso notar que, mesmo considerando a marca indelével deixada por Schopenhauer na filosofia de Nietzsche, principalmente no que concerne à concepção da essência da vida como vontade, desde seus primeiros estudos encontramos neste último uma idéia de vontade absolutamente diferente daquela de seu mestre e inspirador, já que, no pensamento nietzscheano, a vontade não é compreendida como vontade de vida, e sim como vontade criadora, que se intensifica constantemente.

6 NT, §24, p. 142. (KSA, I, p. 153).

7 NIETZSCHE, Friedrich. Tentativa de autocrítica. In: NT, p. 14. (KSA, I, p. 12).

8 NIETZSCHE, Friedrich. A gaia ciência. Tradução, notas, e posfácio Paulo Cézar de Souza. São Paulo: Companhia das Letras, 2001, p. 14. (KSA, III, p. 352).

9 NT, §5 p. 47. (KSA, l, p. 47).

10 É com o termo "niilismo", já empregado por Jacobi, Jean-Paul, Ivan Tourguenieff, Dostoiéwsky e pelos anarquistas russos, mas que Nietzsche toma do crítico e escritor francês Paul Bourget, que ele caracteriza a crise mortal do mundo moderno: a desvalorização universal de todos os valores que mergulha a humanidade no desespero da ausência de sentido. 
idealismo metafísico. Seu pensamento se constrói, portanto, como uma luta incessante contra a metafísica socrática. Neste combate, em $O$ nascimento da tragédia, Nietzsche confere ao verdadeiro artista, gênio transfigurador, a tarefa de restaurar a saúde da cultura ao fazer da arte a exaltação da força vital do homem.

Não é difícil compreender como poucas semanas após deflagrada a Guerra franco-prussiana responsável pela proclamação do Império Alemão (1870/1871), ainda convalescendo em casa de uma enfermidade contraída em campanha, Nietzsche, esse "cismador de idéias e amigo de enigmas","11 meditava incansavelmente sobre a arte grega, os gregos e a tragédia, a questão da relação entre a arte e a vida, em suma, sobre o sentido mesmo da vida assim como ele se manifestou na civilização helênica. Foi neste contexto turbulento que a inquietação do filósofo germinou as idéias que originariam, um ano mais tarde, $O$ nascimento da tragédia, obra definitiva para a sua teoria da arte. Longe de ser apenas um mero "tintinar de guizos", ${ }^{12}$ a arte é, para Nietzsche, principalmente neste momento, o problema mais sério, o mais urgente, aquele do qual depende o futuro da cultura alemã. Em seu entendimento mais profundo, a cultura como autêntica Formação (Bildung) do homem não pode ser confundida com o estado, e a vitória das armas jamais será a sua. É por isso que Nietzsche dedica este livro a Richard Wagner, cuja obra musical ele acreditou ser um verdadeiro renascimento da arte trágica na Alemanha de então, embora mais tarde tenha mudado radicalmente de opinião sobre o compositor, como testemunha, dentre outros escritos, o importantíssimo posfácio que esta obra recebeu dezeseis anos depois, intitulado Tentativa de autocrítica. ${ }^{13}$

Já em $O$ nascimento da tragédia Nietzsche nos apresenta o essencial de sua estética; pela qual ele entende não somente o estudo das obras de arte, mas também e, sobretudo, sua genealogia e seus efeitos na cultura e na vida de um povo. Neste livro, trabalhando com imagens retiradas da mitologia, seu pensamento não visa apenas à "intelecção lógica” (logischen Einsicht).

11 NIETZSCHE, Friedrich. Tentativa de autocrítica. In: NT, p. 13. (KSA, I, p. 11).

12 NT, p. 26. (KSA, I, p. 24).

13 A partir do item 19, O nascimento da tragédia parece sofrer uma brusca mudança de direção. O estudo da arte trágica deixa a frente da cena, e o filósofo passa a concentrar-se na análise do drama musical wagneriano, pensado como redespertar do espírito trágico na cultura alemã, contaminada, aos seus olhos, pelo stilo rappresentativo da opera, herdeira do socratismo estético. Muitos contemporâneos de Nietzsche que não compreenderam a relação por ele estabelecida entre a tragédia e a música de Wagner chegaram a afirmar que este livro acaba por converter-se numa espécie de panfleto propagandístico do célebre compositor. No entanto, se o jovem Nietzsche depositou na música wagneriana todas as suas esperanças de um renascimento alemão, mais tarde ele irá abandonar completamente esta posição, concluindo que contaminou seu primeiro livro com a presença de Wagner, cuja arte não faz outra coisa senão reafirmar uma concepção metafísica e moral da existência. Cf. Tentativa de autocrítica. In: NT, p. 13-23. (KSA, I, p. 13-22). 
Ele opera plasticamente, livre de conceitos, com as "figuras penetrantemente claras" ${ }^{14}$ dos dois grandes deuses da arte grega que, segundo a interpretação heterodoxa de Nietzsche, são Apolo e Dionísio. Compreendidos como impulsos (Triebe) estéticos, poderes artísticos (künstlerische Mächte) que não pertencem ao homem mas à própria natureza, são essas duas pulsões que determinam, em sua constante contraposição de origens e objetivos, o contínuo desenvolvimento da arte. Apolo, o deus da forma, que ilumina a arte do figurador plástico, a apolínea, e Dionísio, pai da arte não figurada da música. Impulsos que, nesta leitura inovadora, se encontram e se reconciliam na tragédia ática, ${ }^{15}$ onde a forma está a serviço do informe, da verdade dionisíaca que encena. Observamos, contudo, que esta filosofia da arte vai além da oposição entre forma (morphé) e matéria (hylé) que orienta a estética clássica: se a arte é, para Nietzsche, fruto da força transfiguradora da embriaguez, a aparência da forma não remete a outra coisa que não seja seu próprio trabalho de potencialização da vida. O que a forma traz consigo é sua própria condição: a verdade da vontade intensificada.

Verdadeira fisiologia da arte, ${ }^{16}$ o pensamento estético de Nietzsche entende o apolíneo e o dionisíaco como instintos artísticos que se satisfazem por meio de estados fisiológicos. De um lado, no sonho, onde a bela aparência (der schöne Schein) da forma se expressa, e, de outro, na embriaguez, manifestação fisiológica do estado dionisíaco. Sonho e embriaguez são, para Nietzsche, os estados estéticos por excelência, que exigem a libertação dos limites da consciência empírica individual. A criação artística não tem por "autor" o eu consciente de si e reconhecível por todos, mas a potência da vida em sua necessidade constante de ultrapassamento de si mesma.

Nietzsche afirma que em seu mundo onírico apolíneo "cada ser humano é um artista consumado". ${ }^{17}$ Contudo, observa que o traço característico da

$14 \mathrm{NT}, \S 1$, p. 27. (KSA, I, p. 25).

15 A tragédia que interessa a Nietzsche é apenas a tragédia ática, aquela de Ésquilo e de Sófocles. Em sua compreensão, com Eurípedes, a tragédia decaiu. Ao expulsar a música do espetáculo trágico, o artista teria excluído seu elemento primordial, o dionisíaco, privilegiando o diálogo e fazendo da tragédia uma arte dirigida à inteligência das arquibancadas. Segundo Nietzsche, o grande mestre de Eurípedes é Sócrates, para quem o grande princípio estético é: "Tudo deve ser inteligível para ser belo". Cf. NT, §12, p. 81. (KSA, I, p. 85).

16 Assim diz a famosa fórmula nietzscheana: "Afinal, a estética não passa de fisiologia aplicada". Cf. NIETZSCHE, Friedrich. Nietzsche contra Wagner. Tradução Paulo Cézar de Souza. São Paulo: Companhia das Letras, 1999, p. 53. (KSA, VI, p. 418). Vale notar que não trabalhamos aqui com uma visão cronológica do pensamento estético de Nietzsche, como sustenta, por exemplo, Mathieu Kessler, que divide a estética do filósofo em duas fases distintas: a primeira, eminentemente romântica, denominada de "metafísica do artista", e, a segunda, chamada de "fisiologia da arte", compreendida como seu momento clássico. Cf. KESSLER, Mathieu. L'esthétique de Nietzche. Paris: PUF, 1998.

17 NT, §1, p. 28. (KSA, I, p. 26). 
bela aparência desta realidade onírica é que temos sempre a "transluzente sensação de sua aparência". ${ }^{18}$ Trata-se de uma aparência que se sabe aparência, ilusão que se vê como ilusão, e jamais se confunde com a realidade empírica. São visões que configuram cenas com as quais vivemos e sofremos, mas que nunca perdem a "fugaz sensação da aparência". Segundo Nietzsche, toda pessoa suscetível ao artístico quando está diante da realidade do sonho contempla-o prazerosamente, e a partir dessas imagens - sejam elas agradáveis e luminosas ou tristes e sombrias - interpreta a vida, exercita-se para a vida. Pois "o nosso ser mais íntimo, o fundo comum a todos nós, colhe no sonho uma experiência de profundo prazer e jubilosa necessidade": ${ }^{19}$ a vontade, nossa mais íntima condição, necessita construir imagens a partir das quais "a vida se torna possível e digna de ser vivida". ${ }^{20}$ Estamos diante da alegre necessidade da beleza reparadora, assim como o é o sono e o sonho, cuja "verdade superior", a "perfeição", se contrapõe à "realidade cotidiana tão lacurnamente inteligível".

Da mesma forma que em meio ao mar enfurecido e ilimitado o barqueiro de um pequenino bote permanece sereno e confiante em sua frágil embarcação - a bela imagem schopenhaueriana de $O$ mundo como vontade e representação, que descreve o homem colhido sob o véu de Maya como aquele que, mergulhado em uma vida de tormentos, encontra calma e apoio no principium individuationis e confia na ilusão da representação para poder viver -, Nietzsche nos mostra o artista apolíneo suportando e dignificando a vida em seu mundo fictício de beleza. ${ }^{21}$

Em $O$ nascimento da tragédia, se a beleza é Apolo, a verdade é Dionísio. E é precisamente o terror que Schopenhauer diz tomar conta do ser humano quando se rasga o véu da representação que nos aproxima do dionisíaco: a verdade do desejo, ao mesmo tempo aterrorizante e extasiante, que experimentamos na embriaguez. Nietzsche fala das beberagens narcóticas que os povos primitivos cantavam em seus hinos, da Babilônia e suas sáceas

18 NT, §1, p. 28. (KSA, I, p. 26).

19 NT, §1, p. 29. (KSA, I, p. 27).

20 NT, §1, p. 29. (KSA, I, p. 27).

21 A filosofia schopenhaueriana sustenta uma dualidade de pontos de vista no tocante ao conhecimento do mundo já inscrita no título de sua obra maior, O mundo como vontade e representação: do ponto de vista da consciência racional, a realidade é nossa representação, ilusão construída por nosso princípio de razão que percebe o mundo fenomenal, sob o princípio de individuação, no espaço e no tempo, e segundo a lei da causalidade - esta é a marca deixada por Kant no pensamento do filósofo; mas, para Schopenhauer, do ponto de vista de nossa experiência interna, ou seja, por intermédio de nosso corpo, estamos em contado direto com a realidade tal como ela é, temos o conhecimento imediato da coisa em si que é a vontade. É precisamente neste ponto que Schopenhauer vai além de Kant, para quem o conhecimento da coisa em si mesma está vedado ao homem. 
orgiásticas que celebravam a união dos homens entre si e com a natureza, da primavera que chega impregnando a atmosfera de alegria... Todos exemplos do que é capaz de despertar o "transporte dionisíaco" onde o "subjetivo se esvanece em completo auto-esquecimento". ${ }^{22}$ No estado dionisíaco "o homem não é mais artista, tornou-se obra de arte: a força artística de toda a natureza, para a deliciosa satisfação do Uno-primordial (Ur-Einen), revela-se aqui sob o frêmito da embriaguez". ${ }^{23}$

Desenvolvendo em um sentido excêntrico a teoria aristotélica da arte como mímese, a estética de Nietzsche define o artista como um "imitador" não porque sua tarefa seja a reprodução, a representação de uma natureza já dada - a mera realidade empírica -, mas na medida em que é capaz de encarnar os poderes artísticos da própria vida, o apolíneo e o dionisíaco, imitando esses dois "estados artísticos imediatos da natureza". ${ }^{24}$ Seja como artista apolíneo da forma, onírico, seja como artista dionisíaco do êxtase ou, como na tragédia ática e seus antepassados, a poesia lírica e a canção popular, enquanto artista ao mesmo tempo apolíneo e dionisíaco.

Ao analisar a relação do artista helênico com esses arquétipos em $O$ nascimento da tragédia, Nietzsche sublinha a diferença decisiva que separa os gregos dionisíacos dos bárbaros dionisíacos, distinção fundamental para a compreensão de sua estética. Na Grécia, em seus "dias de transfiguração", ao contrário, por exemplo, das sáceas babilônicas e sua "retrogradação do homem ao tigre e ao macaco", a experiência aterrorizante do dionisíaco transformouse em fenômeno artístico: as festas dionisíacas gregas conheceram a música, a embriaguez se fez arte; apenas com elas o rompimento do principium individuationis tornou-se um fenômeno estético. Entre os gregos, o elemento devastador que é próprio da vontade foi neutralizado pelo processo artístico de simbolização. Preciosa conclusão: Dionisío necessita ser expresso para que não se torne destruidor. Neste ponto, vislumbramos de forma concentrada toda a ética que a estética de Nietzsche nos propõe: aquela da relação entre a arte e a vida, o próprio sentido da cultura como Formação, como processo de transformação do desejo, trabalho infinito de dar forma às paixões humanas para que, transfiguradas, elas possam descarregar-se artisticamente.

Nietzsche acredita que até o século VII a.C. os gregos não conheciam a verdadeira música: a música dionisíaca; eles conheciam somente a música

22 NT, §1, p. 30. (KSA, I, p. 29).

23 NT, §1, p. 31. (KSA, I, p. 30). Neste momento da obra de Nietzsche, a realidade é pensada como vontade única, como indica a expressão Uno-primordial. Já nos escritos da última fase esta expressão é abandonada, e a realidade aparece descrita com o termo "vontade de potência".

24 NT, §2, p. 32. (KSA, I, p. 30). 
tocada por aedos que recitavam os poemas de Homero acompanhados pela cítara, a música apolínea. Uma música que foi qualificada como tal por imprecisão de linguagem, já que manejava apenas as forças plásticas e arquiteturais do som: "enquanto batida ondulante do ritmo" recortava figuras no tempo. Para Nietzsche, só mais tarde surge na Grécia a música propriamente dita, a dionisíaca, que é expressão direta do querer, do prazer e da dor, daquilo que há de metafísico no mundo físico. Caracterizada pela "comovedora violência do som", pela "torrente unitária da melodia e o mundo absolutamente incomparável da harmonia", ${ }^{25}$ esta música, então tocada principalmente pela flauta, era capaz de incitar o homem à máxima intensificação de suas capacidades simbólicas. Com ela, a vontade, o íntimo da natureza, encontrava sua expressão corporal completa, na mímica, na dança e no canto cultual em honra a Dionísio, o ditirambo dionisíaco.

Seguindo os passos de pensadores como Hölderlin e Bachofen - que também viam a Grécia como solo do incomensurável -, embora trilhando sua própria senda, o traço distintivo da interpretação nietzscheana do mundo helênico é o dionisíaco. Em sua filologia-filosófica, que escandalizou a comunidade dos filólogos de seu tempo, ele rompe com a imagem tradicional da Grécia como império da medida e da beleza (idéia sustentada por classicistas alemães como Schiller, Goethe e Winckelmann) e enxerga por trás de todo comedimento apolíneo, da "serenojovialidade" idílica dos gregos, a desmedida, a hybris, todo o ilimitado do desejo, enfim, a verdade impetuosa da vontade e revela seu mistério: o trabalho artístico de transfiguração. Se os helenos conseguiam entrever em cada canto o riso de Helena, filha de Zeus e a mais bela dentre as mulheres, é porque traziam em seu corpo o "filtro mágico" da arte.

Foi na sabedoria popular grega que Nietzsche deparou com o dionisíaco, encarnado na figura do sábio Sileno. Preceptor e servidor de Dionísio, filho de Pã - o deus grego dos rebanhos e dos pastores cuja flauta suscitava súbitos e infundados terrores -, Sileno é um semideus, representado quase sempre como um velho careca, de nariz chato e arrebitado, sempre bêbado e montado num asno ou amparado por sátiros que acompanhavam o cortejo do deus por toda parte. Para Nietzsche, é de sua ebriedade que fala a voz mais profunda do saber e da filosofia: o conhecimento trágico da finitude, do caráter efêmero da vida humana, a convicção de que o melhor para os homens, "filhos do acaso 
e do tormento", seria "não ter nascido, não ser, nada ser", ${ }^{26}$ e, depois disso, logo morrer.

Ao compreender o estreito liame entre o maravilhoso mundo apolíneo que se expressa, antes de tudo, nas grandiosas figuras dos deuses olímpicos, e essa terrível sabedoria de Sileno, Nietzsche nos mostra sua "recíproca necessidade": "O grego conheceu e sentiu os temores e os horrores do existir: para que lhe fosse possível de algum modo viver, teve de colocar ali, entre ele e a vida, a resplendente criação onírica dos deuses olímpicos". ${ }^{27}$ Ao ver sua existência ser vivida por estes seres super-humanos, ela ganha sentido, dignidade para ser vivida. Abre-se então a montanha mágica do Olimpo, e o filósofo desvenda o segredo e a necessidade da arte: a arte, esse "mundo intermédio", vem encobrir e subtrair ao olhar a verdade pessimista de Sileno. Os gregos criam deuses para poderem viver; sem o véu de beleza apolíneo, a vida humana seria simplesmente insuportável. Com uma esplêndida metáfora Nietzsche descreve: suas obras de arte "são como rosas a desabrochar da moita espinhosa". ${ }^{28}$ Ao lado da exacerbada aptidão para o sofrimento, os helenos possuem seu talento de artistas. Se este povo tão impetuoso no desejo foi capaz de suportar a existência, é porque esta é transformada pela arte, mágico "espelho transfigurador" que legitima a vida humana, intensifica-a, afirmando-a. Assim, entre os gregos, a sabedoria trágica do velho Sileno é invertida, e "a pior coisa de todas é para eles morrer logo; a segunda pior é para eles morrer um dia". ${ }^{29}$ Porque a "vontade" anseia "veementemente" pela existência quando ela é envolvida pela glória da arte.

Nietzsche sublinha que os modernos insistem em atribuir aos gregos uma ingenuidade que eles não têm; que a harmonia grega contemplada nostalgicamente pelo classicismo - para a qual Schiller cunhou o termo artístico naïf - não é de forma alguma um estado simples e natural que se encontra na origem de toda cultura, como idílico paraíso primeiro. Ao contrário, aquela "serenojovialidade", a calma e nobreza características dos gregos, constitui o efeito supremo da cultura apolínea, que teve primeiro que domar a dor, fazendo-se vitoriosa sobre "uma horrível profundeza da consideração do mundo [Weltbetrachtung] e sobre a mais excitável aptidão para o sofrimento". ${ }^{30}$ Com a beleza de Apolo, o grego inverte a verdade demoníaca presente em sua sabedoria popular. Segundo o filósofo, a ilusão 
apolínea é semelhante àquela que a natureza freqüentemente emprega para atingir seus objetivos: a verdadeira meta, a possibilidade da vida, é encoberta pela imagem ilusória da arte em direção à qual estendemos as mãos.

Nesta interpretação, a cultura grega tem a divinização da vida como valor supremo. Trata-se de uma autêntica celebração da existência acima de qualquer avaliação metafísica e moral. A religiosidade grega, eminentemente artística, a esfera superior do mundo dos deuses, é desprovida de imperativos ou censura e, em sua perfeição, a vontade se glorifica. Na religião primitiva dos gregos, a vida é transfigurada em beleza, a verdade se faz arte. Eis a lição que os helenos nos legam em seus mitos e que na avaliação de Nietzsche ganha uma atualidade surpreendente e transformadora. Sem nostalgia, esta é a herança que nos foi deixada por este povo singular, cujo aprendizado constitui a tarefa mais urgente, capaz de transformar o presente e salvar o futuro da cultura ocidental, segundo a convicção de Nietzsche.

$\mathrm{Na}$ esteira de Schopenhauer, para Nietzsche, é na aparência que a verdade encontra sua redenção. A simbolização da forma é vista como um poder da individuação que se opõe à força desagregadora da vontade. Aqui jaz o parentesco entre o artista e o filósofo: se para o olhar deste último nossa existência empírica, assim como a do mundo em geral, é uma representação da vontade, do Uno-primordial, que enquanto "eterno padecente e pleno de contradição necessita, para a sua constante redenção, também da visão extasiante, da aparência prazerosa", ${ }^{31}$ a arte é então "a aparência da aparência" (Schein des Scheins), uma mais elevada satisfação do impulso primeiro pela aparência. Da "eterna dor primordial, único fundamento do mundo", ${ }^{32}$ elevase o mundo visional das imagens de Apolo. E a arte põe em cena a grande suposição metafísica de Nietzsche: a relação entre aparência e verdade. Já que apenas com o "filtro mágico" da aparência podemos ter acesso à verdade.

Em sua busca para desvendar o mistério da união do apolíneo e do dionisíaco em $O$ nascimento da tragédia, Nietzsche depara com Arquíloco, ${ }^{33}$ pai da poesia lírica. Ao lado de Homero, o grande poeta épico, surge o apaixonado e belicoso poeta lírico, que canta as vissicitudes de suas paixões e "sempre diz eu", podendo assim representar o protótipo do artista subjetivo. No esforço de esclarecer esta poética e solucionar o problema estético relativo à possibilidade do poeta lírico enquanto artista - já que só podemos conceber

33 Este famoso poeta grego, que viveu aproximadamente no século VII a.C., apaixonado por Neobule e impedido de desposá-la pelo pai da moça, Licambes, vingou-se com sátiras tão mordazes que, dizem, pai e filha enforcaram-se. 
o artista subjetivo como um mau artista, pois a arte exige acima de tudo a "submissão do subjetivo" e a objetiva e "pura contemplação desinteressada" ${ }^{34}$-, Nietzsche encontra as pistas que lhe permitem solucionar o enigma da tragédia: o poeta lírico só é possível enquanto artista porque sua poesia, aparentemente subjetiva, se inicia com "um estado de ânimo musical", e portanto dionisíaco, onde sua subjetividade empírica se esvanece, que, em seguida, se descarrega em um mundo de imagens apolíneo.

Ele se fez primeiro, enquanto artista dionisíaco, totalmente um só com o Unoprimordial, com sua dor e contradição, e produz a réplica desse Uno-primordial em forma de música, [...] agora porém esta música se lhe torna visível, como uma imagem similiforme do sonho, sob a influência apolínea do sonho. ${ }^{35}$

No processo dionisíaco, o poeta lírico já renunciou à sua subjetividade. É desse fundo de embriaguez, dessa subjetividade transbordada, que nascem as imagens cuja "coloração, causalidade e velocidade" são completamente diferentes daquelas presentes na poesia épica. O que aqui se simboliza é o abismo do ser, a vontade, "o gênio universal", "única 'eudade' (Ichheit) verdadeiramente existente e eterna, em repouso no fundo das coisas". ${ }^{6} \mathrm{Se}$, na estética de Nietzsche, o indivíduo é o adversário da arte, neste caso preciso, o poeta torna-se obra de arte da vontade, o grande "artista dionisíaco dos mundos". Somente assim ele pode saber algo a respeito da "perene essência da arte", onde é a embriaguez que impulsiona a criação: uma subjetividade para além de si mesma, pura afetividade que extrapola os limites da consciência subjetiva. Este é todo o mistério do poeta lírico.

A música é o "espelho do mundo". Dentre todas as artes, só ela tem o poder de expressar a essência das coisas, a vontade, embora seja incapaz de libertar-nos desta: assim ensina Schopenhauer em sua profunda metafísica da música que tanto influenciou Richard Wagner e Nietzsche. O item 16 de $O$ nascimento da tragédia reproduz, em sua longa extensão, uma passagem de $O$ mundo como vontade e representação que conduz ao cerne dessa compreensão

34 Idem, §5, p. 43. (KSA, I, p. 43). A estética de Nietzsche tem sua matriz na Terceira Crítica de Kant. O desinteresse, qualidade fundamental da contemplação estética segundo a Crítica da faculdade do juízo kantiana, é decisivo tanto para a estética de Schopenhauer, onde a contemplacão das belas formas representa uma libertação provisória da escravidão da vontade, quanto para aquela de Nietzsche, já que apenas despido de seus interesses individuais pode o homem entrar no reino da arte. No entanto, segundo Nietzsche, "Kant, como todos os filósofos, em vez de encarar o problema estético a partir da experiência do artista (do criador), refletiu sobre a arte e o belo apenas do ponto de vista do 'espectador'”. Cf. NIETZSCHE, Friedrich. Genealogia da moral: uma polêmica. Tradução, notas e posfácio Paulo Cézar de Souza. São Paulo: Companhia das Letras, 1998, III, §6, p. 93. (KSA, V, p. 346).

35 NT, §5, p. 44. (KSA, I, p. 43).

36 NT, §5, p. 45. (KSA, I, p. 45). 
da arte musical, presenteando-nos com pequenas pérolas shopenhauerianas fundamentais para o entendimento da estética de Nietzsche. Segundo Schopenhauer, a música é o "reflexo imediato da própria vontade, portanto, representa o metafísico para tudo que é físico no mundo". ${ }^{37}$ De forma que poderíamos "chamar o mundo todo tanto de música corporificada quanto de vontade corporificada". ${ }^{38}$ Enquanto "linguagem universal", a música proporciona o acesso ao "núcleo mais íntimo, que precede toda configuração, ou seja, o coração das coisas". ${ }^{39}$ Ela "é a Idéia imediata dessa vida", ${ }^{40}$ escreve Nietzsche. Somente a música permite a conecção com o único verdadeiro criador do mundo da arte: a eterna vontade. É por isso que, diferente das artes figurativas, a música, em sua incomensurabilidade, não se deixa medir segundo a categoria de beleza.

$\mathrm{Na}$ canção popular (Volkslied), Nietzsche também verifica a união da imagem e da música, ou seja, do elemento apolíneo e do dionisíaco. Ela é música e letra: enquanto espelho musical do mundo, a canção popular é "melodia primigênia" que se exprime em poesia. Mas, para Nietzsche, a melodia é sempre primeira, mais importante e universal, pois "a palavra jamais poderá volver para fora o imo da música". "Essa é a única relação possível entre poesia e música, palavra e som. Um dos temas principais que atravessa todo o primeiro livro de Nietzsche, como destaca Rosa Dias, ${ }^{42}$ é o da supremacia expressiva da música em detrimento da significação sempre limitada das palavras. Nietzsche está convicto de que é impossível com a linguagem alcançar por completo o "simbolismo universal da música". Posição que reivindica uma nova concepção da verdade filosófica, liberada do registro discursivo e da lógica característicos da metafísica socrática, se confundindo com a "beatitude" trágica que a música é capaz de suscitar. ${ }^{43}$

Para adentrar no verdadeiro "labirinto" que a emergência da tragédia ática revela ser, Niezsche emprega o mesmo argumento dado tanto para a poesia lírica quanto para a canção popular: a origem da tragédia está no espírito da música. No drama trágico, a música é primária, e o diálogo é secundário. Como obra de arte apolíneo-dionisíaca, a tragédia reúne sonho e embriaguez,

43 Sobre a relação entre música e verdade em Nietzsche, remetemos aqui ao grande livro de Clement Rosset, Alegria: a força maior, tradução de Eloisa Araújo Ribeiro (Rio de Janeiro: Relume Dumará, 2000. p. 44 et seq.). 
luz e sombra, aparência e essência, imagem e música. A tragédia nasceu da música, do canto em louvor a Dionísio, entoado por um grupo de pessoas que percorrendo florestas faziam-se passar por sátiros, seres naturais-fictícios, homens com pés de capro e pequenos chifres. Em estato extático, com o rosto pintado da seiva de diferentes plantas e a testa coberta de flores, estas criaturas híbridas erravam pelos matos cantando, dançando e tocando flauta rústica. Esse coro de sátiros, conjunto de seres transformados, a um só tempo atores e expectadores, via desenrolar diante de si um espetáculo visível apenas para aqueles que participavam da excitação dionisíaca. Apenas posteriormente a tragédia passou a apresentar-se em um teatro.

O fenômeno de possessão provocado pela música, a embriaguez, é a condição e o princípio da arte dramática. Porque, acredita Nietzsche, ela suscita o despojamento da civilização e a participação da realidade primordial, anterior à individuação. É nesta última que penetram os sátiros. Cantando e dançando, eles anulam o eu humano e se transformam em autênticos seres naturais. Eis a importância e o significado do coro na tragédia: como Schiller esclarece, o coro é "como uma muralha viva que a tragédia estende à sua volta a fim de salvaguardar para si o seu chão ideal e a sua liberdade poética" ${ }^{44}$ Com o fingido estado natural produzido pela música, a tragédia está, desde o princípio, desobrigada de efetuar uma penosa retratação servil da realidade: ela se relaciona imediatamente com a verdade do desejo, a realidade originária.

A embriaguez musical descortina um real que é mais real que a realidade empírica, uma "realidade reconhecida em termos religiosos". ${ }^{45} \mathrm{Na}$ imagem precisa de Richard Wagner, a civilização "é suspensa pela música tal como a claridade de uma lâmpada o é pela luz do dia". ${ }^{46}$ E o efeito imediato da tragédia não é, como afirmou Aristóteles na Poética, a catarse, este misto de piedade e medo que faz com que os espectadores, enlevados pelas melodias sagradas, deixem o teatro com a alma acalmada e os afetos em estado de pureza. De forma muito diferente, para Nietzsche, o efeito da tragédia dionisíaca é tonificante, confunde-se com a experiência da própria liberdade que dissolve a arbitrariedade e as convenções da civilização, substituindoas por "um superpotente sentimento de unidade que reconduz ao coração da natureza". ${ }^{47}$ A embriaguez promete embriaguez. O "consolo metafísico" é o efeito da tragédia: a certeza imediata "de que a vida, no fundo das coisas, 
apesar de toda mudança das aparências fenomenais, é indestrutivelmente poderosa e cheia de alegria". ${ }^{48}$ Com a tragédia, os gregos, esse povo movido pelo ímpeto, encontram seu conforto: "ele é salvo pela arte, e através da arte salva-se nele - a vida". ${ }^{49}$

Símbolo da vontade, da onipotência sexual da vida, o sátiro anuncia a sabedoria que vem do seio mais profundo da natureza. É ele quem diz a verdade. $\mathrm{E}$ a arte que dele se origina, o drama trágico, o conjunto da música e do mito trágico, constitui a sua mais autêntica expressão. Ela nos apresenta a "verdade da natureza" em contraste com a "mentira da civilização". Porque o grego dionisíaco "quer a verdade e a natureza em sua máxima força". 50 Definida como "coro dionisíaco a descarregar-se sempre de novo em um mundo de imagens apolíneas", ${ }^{51}$ a tragédia ao mesmo tempo diz a verdade e a transfigura. A cena é visão, a única realidade é o coro que contempla nessa visibilidade o padecimento e a glorificação de seu mestre e senhor Dionísio, que, como sábio, do coração do mundo enuncia o conhecimento trágico. Aqui temos a força e a forma, o desejo e suas imagens que, enquanto produto do processo de simbolização, potencializam a vontade, intensificam-na.

$\mathrm{Na}$ filosofia de Nietzsche, a criação artística é a força transfiguradora da embriaguez. E a própria existência humana pode ser concebida como um ato artístico contínuo, uma constante criação de si que parte dessa afetividade originária, solo de todas as coisas. Assim, esta estética pensa a forma como o próprio conteúdo da arte, sua única matéria. Se na obra de Nietzsche existe um princípio estético, é nesta curta passagem que ele o enuncia: "Se é artista sob a condição de sentir como conteúdo, como a própria coisa, o que os não artistas chamam de "forma'." 52 Para Nietzsche, a aparência da forma não remete a outra coisa senão a ela mesma, sua tarefa é de intensificação. Testemunho da força, visibilidade da vontade que permanence invisível, a forma traz consigo sua própria condição e ao mesmo tempo a produz, a cria a partir de si. Como força, a forma tem o poder de criar seu próprio conteúdo, é criação de si que faz cair por terra a distinção metafísica entre ser e aparecer - que uma primeira

48 Idem, ibidem. A alegria é, na visão de Nietzsche, o pathos trágico por excelência. Neste sentido, é possível pensar que em $O$ nascimento da tragédia já se encontra presente, mesmo que de forma embrionária, a idéia central da filosofia nietzscheana, o pensamento do eterno retorno: a compreensão do tempo como repetição, que traz consigo a exigência de afirmação radical da vida, onde a intensidade do instante alegre abriga toda a eternidade. Quase ao final de seu primeiro livro, Nietzsche escreve, referindo-se aos gregos: "[...] o presente mais próximo havia de se lhes apresentar desde logo sub specie aeterni [sob o aspecto da eternidade] e, em certo sentido, como intemporal”. NT, §23, p.137. (KSA, I, p. 147).

49 Idem, ibidem.

50 NT, §8, p. 58. (KSA, I, p. 59).

51 NT, §8, p. 60. (KSA, I, p. 62).

52 NIETZSCHE, Friedrich. Fragments posthumes, 18[6], XIV, p. 281. (KSA, XIII, p. 533). 
leitura de $O$ nascimento da tragédia pode sugerir ${ }^{53}$-, excedendo os limites dentro dos quais toda a filosofia da arte anterior a Nietzsche moldou seus conceitos. Estamos diante de uma espécie de aparência pura, como nomeou Paul Audi, que extrapola as noções de forma e matéria legadas pela estética clássica.

Em O nascimento da tragédia, o conteúdo da arte não é da ordem de um "significado" que lhe seja exterior, passível de tornar-se objeto de um logos ou intelecção. Esse conteúdo é "significativo", ${ }^{54}$ diz respeito a um certo pathos primordial que Nietzsche chamará mais tarde de "sentimento de existir". A significatividade da forma é um "valor", é aprovação, "divinização da existência"; não fala apenas ao nosso entendimento, mas à totalidade de nosso ser. Desta maneira, ao abrir o campo do sentido, a arte está investida do poder de deslocar a transcendência para o plano de imanência da vida.

Desde seus primeiros estudos Nietzsche nos ensina que é preciso amar a forma por isto que ela é: afirmação. Única saída para a decadência. Em outras palavras, para esta filosofia, a existência da obra de arte se origina da força transfiguradora do amor que, na efusão infinita de sua embriaguez, se libera como generosidade e transbordamento. A essência da criação só se realiza no e pelo amor, a forma suprema do júbilo. Com essa nobre idéia, unemse definitivamente a ética e a estética, como um dos últimos Fragmentos póstumos do filósofo enuncia maravilhosamente:

Até onde pode ir a força transfiguradora da embriaguez, dela se quer a prova mais surpreendente? Essa prova é o "amor", isso que se chama amor em todas as línguas, em todos os mutismos do mundo. [...] como uma febre que tem razões para se transfigurar, uma embriaguez que faz bem em mentir por sua própria conta... Em todo caso, se mente bem quando se ama, mentimos, mentimos por sua conta: nos imaginamos transfigurados, mais fortes, mais ricos, mais perfeitos, somos mais perfeitos... Nós encontramos aqui a arte como função orgânica: nós a encontramos infiltrada no instinto mais angélico da vida: nós a encontramos como o maior estimulante da vida - arte portanto, de maneira sublime adaptada aos seus fins, no seu mentir... Mas nós nos enganaríamos se permanecêssemos em sua faculdade de mentir: é preciso mais, ela desloca os valores... O amoroso tem mais valor, é mais forte. Nos animais, esse

53 Notamos aqui que muitos comentadores reafirmam a visão que o próprio Nietzsche mais tarde passa a ter de seu primeiro livro: uma obra marcada pela contradição dialética entre Apolo e Dionísio, entre a essência e a aparência, que cheira a hegelianismo. Mesmo Gilles Deleuze que, em Nietzsche e a filosofia, de 1962, apresentou uma leitura atualíssima desta obra, responsável em muito pelo seu reflorescimento em todo o mundo, não deixa de marcar que ainda encontramos em $O$ nascimento da tragédia a presença do dualismo e da oposição característicos do pensamento dialético que busca uma reconciliação, posição que será abandonada por Nietzsche quando este alcança a verdadeira afirmação. Cf. DELEUZE, Gilles. Nietzsche e a filosofia. Tradução Edmundo Fernandes Dias e Ruth Joffily Dias. Rio de Janeiro: Rio, 1976. p. 7 et seq.

54 AUDI, Paul. Op. cit., p. 42. 
estado faz surgir novas substâncias, novos pigmentos, novas cores, novos ritmos, novos gritos de chamada e novas seduções. No homem não é diferente. Seu fundo geral é mais rico que nunca, mais potente, mais inteiro que naquele que não ama. $\mathrm{O}$ amoroso se torna perdulário: ele é rico suficiente para isso. Doravante se arrisca, se torna aventuroso, se torna um verdadeiro asno de magnanimidade e inocência; ele acredita novamente em Deus, ele acredita na virtude porque crê no amor: e, de um outro lado, nesse idiota da felicidade, ele faz nascer asas e faculdades novas, e mesmo as portas da arte se abrem para ele. Tiremos do lirismo musical e verbal as sugestões nascidas desta febre intestinal: o que resta do lirismo e da música?... A arte pela arte talvez: o coachar virtuoso das rãs resfriadas que desesperam no mar... Todo o resto, foi o amor que criou... ${ }^{55}$

\section{Referências}

AUDI, Paul. L'Ivresse de l'art. Nietzsche et l'esthétique. Paris: Le Livre de Poche, 2003.

DELEUZE, Gilles. Nietzsche et la philosophie. Paris: PUF, 1962.

DELEUZE, Gilles. Nietzsche. Paris: PUF, 1965.

DIAS, Rosa Maria. Nietzsche e a música. Rio de Janeiro: Imago, 1994.

KESSLER, Mathieu. L'esthétique de Nietzsche. Paris: PUF, 1998.

NIETZSCHE, Friedrich. Sämtliche Werke. Kritische Studienausgabe. Org. Giorgio Colli e Massimo Montinari. München: Deutscher Taschenbuch Verlag; Berlin/New York: Walter de Gruyer, 1967-1977. 15 v.

NIETZSCHE, Friedrich. Fragments posthumes. In: Euvres philosophiques completes. Paris: Gallimard, 1968-1997. 18 v.

NIETZSCHE, Friedrich. O nascimento da tragédia, ou Helenismo e pessimismo. Tradução, notas e posfácio J. Guinsburg. São Paulo: Companhia das Letras, 1992.

NIETZSCHE, Friedrich. Genealogia da Moral: uma polêmica. Tradução, notas e posfácio Paulo Cézar de Souza. São Paulo: Companhia das Letras, 1998.

NIETZSCHE, Friedrich. Nietzsche contra Wagner. Tradução Paulo Cézar de Souza. São Paulo: Companhia das Letras, 1999.

NIETZSCHE, Friedrich. Estética y teoria de las artes. Prólogo, seleção e tradução A. Izquierdo. Madrid: Editorial Tecnos, 1999.

NIETZSCHE, Friedrich. A gaia ciência. Tradução, notas e posfácio Paulo Cézar Souza. São Paulo: Companhia das Letras, 2001.

NIETZSCHE, Friedrich. Assim falou Zaratustra: um livro para todos e para ninguém. Tradução de Mario da Silva. Rio de Janeiro: Civilização Brasileira, 2005. ROSSET, Clement. Alegria: a força maior. Tradução de Eloisa Araújo Ribeiro. Rio de Janeiro: Relume Dumará, 2000. 